Purnadi, Kuat,T., \& Santosa, B. (2018). Effectiveness of the Device Network Application Initiative learning model towards the students' information and communication technology skills. Journal of Vocational Education Studies, 1(1), 1-6. DOI: https://doi.org/10.12928/joves.v1i1.586.

\title{
Effectiveness of the Device Network Application Initiative learning model towards the students' information and communication technology skills
}

\author{
Purnadi $^{*}$, Tri Kuat ${ }^{2}$, Budi Santosa ${ }^{2}$ \\ ${ }^{1}$ SMK Muhammadiyah 1 Klaten, Jl. Ki Ageng Pengging 40, Klaten, Indonesia \\ 2 Universitas Ahmad Dahlan, Jl. Pramuka 42, Sidikan, Yogyakarta, Indonesia \\ *Corresponding author, e-mail: muhpurnadi@gmail.com
}

\begin{abstract}
Vocational High School (VHS) students can be qualified if they have competence related to the industry needs. The synchronization of the curriculum with the industry is absolutely necessary, so the school is not left behind by the development of the business world and the industrial world. The development of learning model should always be updated through curriculum innovation, so that schools can synergize with the business and industrial world. This study aims (1) to know the implementation of the Device Network Application Initiative (DNA Initiative) learning model, (2) to know the advantages and disadvantages of applying the DNA Initiative learning model, (3) to know the effectiveness of the DNA Initiative learning model for the students' skill in information technology. The DNA Initiative learning model is the application of industrial curriculum to VHS education. The business world and the industrial world are more confident with students who get their learning materials of industry standard. This study uses a qualitative method. The research was conducted by observation, interview, and documentation. Data analysis techniques used descriptive analysis techniques. Secondary data in the form of documentation was used to support the research. Focus Group Discussion by presenting business and industrial world, curriculum experts, industrial class managers, users, graduates, and teachers' testimonials concluded that the implementation of the DNA Initiative learning model for vocational students is very effective and appropriate. The contribution to schools is the implementation of Prosser's concept that schools are industrial environments or industrial replicas.
\end{abstract}

Keywords: Business and industrial world, DNA initiative, Vocational high school.

\begin{abstract}
Abstrak
Siswa Sekolah Menengah Kejuruan (SMK) terkualifikasi jika siswa memiliki kompetensi sesuai dengan kebutuhan industri. Sinkronisasi kurikulum dengan industri mutlak diperlukan agar sekolah tidak ketinggalan dengan perkembangan dunia usaha dan dunia industry (DUDI). Pengembangan model pembelajaran harus selalu diperbarui atau dilakukan inovasi kurikulum, sehingga sekolah dapat bersinergi dengan DUDI. Penelitian ini bertujuan untuk (1) mengetahui penerapan model pembelajaran Device Network Application Initiative (DNA Initiative), (2) untuk mengetahui kelebihan dan kekurangan penerapan model pembelajaran (DNA Initiative), (3) untuk mengetahui efektivitas model pembelajaran (DNA Initiative). DNA Initiative adalah aplikasi kurikulum industri untuk pendidikan SMK. DUDI lebih percaya diri dengan siswa yang mendapatkan materi pembelajaran standar industri. Penelitian ini menggunakan metode kualitatif. Penelitian ini dilakukan dengan observasi, wawancara, dan dokumentasi. Teknik analisis data menggunakan teknik analisis deskriptif. Data sekunder dalam bentuk dokumentasi digunakan untuk mendukung penelitian. Diskusi kelompok terpumpun dengan menghadirkan DUDI, pakar kurikulum, manajer kelas industri, lulusan, pengguna lulusan, guru dan testimonial, menyimpulkan bahwa penerapan model pembelajaran DNA Initiative untuk siswa SMK sangat efektif dan tepat. Kontribusi untuk sekolah adalah implementasi konsep Prosser bahwa sekolah adalah lingkungan industri atau replika industri.
\end{abstract}

Kata Kunci: Dunia usaha dan dunia industry (DUDI), DNA Initiative, SMK. 


\section{INTRODUCTION}

Learning model is a learning activity that is designed or developed by using certain learning patterns. Learning patterns can describe the activities between teachers and learners in realizing learning conditions or environmental systems that cause the learning process. Learning patterns explain the characteristics of a series of activities undertaken by teachers with learners (Joyce, Calhun, \& Hopkins, 2008). Device Network Application (DNA) Initiative is a curriculum developed for vocational school with difficulty level tiered. DNA Initiative is a learning model that equips students in the field of hardware-based mobile, network, and software applications.

The curriculum has a central position in the entire educational process. The curriculum directs all forms of educational activity for the achievement of educational goals. The curriculum "prescribes (or at least anticipates) the result of instruction" (Finch \& Crunkilton, 1999). The curriculum is also an educational plan, providing guidance on the type, scope, and sequence of educational content and process.

The concept of curriculum develops in line with the development of educational theories and practices. The curriculum is not just a collection of subjects, but the curriculum emphasizes more on learning experiences. The commonly accepted definition of the curriculum has changes from content of course of study and list of subject and courses to all the experiences which are offered to learners under the auspices or direction of the school (Karnes et al., 1999).

Competence of vocational students should be able to balance the development of the business world and industry. Or else, it will only create unemployment that will increase every year. Unemployment at the vocational high school (VHS) level is also the highest number at the time. According to the Indonesian Central Bureau of Statistic (BPS), the number of unemployment in 2016 reached 7,024,172 people (BPS, 2016). The number cannot be accommodated in the company and the awareness of opening a business or selfentrepreneurship is also still low. Moreover, the Indonesian entrepreneurial figure scored 21.2 or ranked 90 out of 137 countries (Acs, Szerb, \& Lloyd, 2017). This shows the importance of building a high work ethic by implementing entrepreneurship so that unemployment at the vocational school level can be reduced.

Technology education is an integral component that is important in the world of education as a whole. This is because technology has penetrated into every space of human life. The so-called technological literacy for the educated community is an integral part of the overall educational orientation (Stevenson, 2003; Stevenson, 2007).

\section{RESEARCH METHOD}

This research was conducted in an effort to obtain a picture of the problem of the effectiveness of implementation of Device Network Application Initiative (DNA Initiative) learning model in the information technology expertise. The research method chosen is qualitative research method. According to Moleong (2007), in the qualitative approach, the data collected generally shaped words, images, and not numbers, even if there are numbers only as supporting characters. The data includes interview transcripts, field notes, photographs, personal documents, notes, and other records. It is for this reason that a qualitative-descriptive approach is chosen.

The qualitative approach also refers to explanations of Straus \& Corbin (1990), who explain that qualitative research explores the beliefs of researchers based on the research experience and the nature of the problem. Qualitative methods can also be used to discover and understand what lies beside many phenomena about what little is unknown. Qualitative methods are also used to gain new and fresh insights, can provide a detailed, complex, and

Purnadi, Kuat,T., \& Santosa, B. (2018). Effectiveness of the network device application initiative learning model towards the students' information and communication technology skills. Journal of Vocational Education Studies, 1(1), 1-6. DOI: https://doi.org/10.12928/joves.v1i1.586. 
very difficult phenomenon revealed by quantitative methods. The same thing is also expressed by Moleong (2007) who explain that qualitative research is a procedure of data collection that produces descriptive data in the form of written or oral words of people and behavior that can be observed.

\section{RESULTS AND DISCUSSION}

Effectiveness is the compatibility between the person performing the task and the intended target. Effectiveness is how an organization succeeds in obtaining and utilizing resources in an effort to realize operational goals (Mulyasa, as cited in Isa, 2010). Effectiveness is something that has the effect or effect generated, efficacious, bring results and is the success of a business or action, in this case effectiveness can be seen from the achievement or absence of specific instructional goals that have been declared (BPPB, 2016). Effectiveness also means successful, precise, efficacious. Effectiveness as success in an action or effort implementation of learning model Device Network Application (DNA) Initiative as application of industrial curriculum at VHS level majoring in information technology.

Vocational education is a secondary education that prepares learners primarily to work in a particular field. The vocational education prepares participants to learn to have a job with certain applied skills in the form of diploma programs and applied undergraduate degree, applied magister, and applied doctorate. Vocational education in Indonesia includes the general VHS and the Madrasa VHS. According to the Indonesian Law number 20/2003 about the National Education System, the national education functions to develop the ability and form the character and civilization of dignified nation in order to educate the life of the nation, aimed at the development of the potential participants of learning, and strengthen their faith to God Almighty, morality, healthy, knowledgeable, capable, creative, independent, and become responsible and democratic citizens (MONE, 2003).

The problem in many developing countries are how to strengthen the links between education and employment preoccupies policymakers (Depdiknas, 2016). In the fast growing countries, this preoccupation stems from the concern that the economy's demand for skilled workers will outstrip its supply. In countries where economic growth is slow, the concern may arise as a result of growing unemployment among young people. In both cases this attention often turns into efforts to make curricula more vocational, to involve employers in schooling decisions, to increase pre-employment training, or to create incentives for employers to participate in apprenticeship training. These attributes are all associated with the dual system. The dual system is attractive for countries at all stages of development, for example in Czech Republic, Egypt, Indonesia, Jordan, Korea, and Poland all have some form of this system, and other countries, such as Kazakhstan, Tanzania, and Zambia, are considering adopting this approach. The implementation of dual system education as a strengthening in the relationship between education and employment. In some developing countries with high unemployment rates can be reduced by training for young workers to work in the company. These trainings involve educational institutions and companies for internship training in companies. In some countries the Czech Republic, Egypt, Indonesia, Jordan, Korea and Poland all have some form of this system, and other countries, such as Kazakhstan, Tanzania, and Zambia, consider also adopting this dual system approach (Surachim, 2016).

In our case, we conducted a Focus Group Discussion attended by BLC Telkom Klaten, curriculum expert, DNA Initiative class manager, Langgam Celuler, and the teacher. We formulized that the implementation of DNA Initiative learning model needs to follow some stages, namely provision of certified DNA labs, preparation of the DNA Initiative syllabus,

Purnadi, Kuat,T., \& Santosa, B. (2018). Effectiveness of the network device application initiative learning model towards the students' information and communication technology skills. Journal of Vocational Education Studies, 1(1), 1-6. DOI: https://doi.org/10.12928/joves.v1i1.586. 
synchronization of industrial curriculum, implementation of learning with the curriculum of DNA, implementation of street vendors/internship work, exam and certification, opening of ESP (Evercos Service Partner), evaluation, and cooperation improvement.The results suggest that all parties regarded that the Device Network Application Initiative (DNA Initiative) learning model is highly effective and highly relevant to mobile device development.

\section{CONCLUSION}

The learning model of Device Network Application (DNA) Initiative at VHS Muhammadiyah 1 Klaten is carried out with several stages, including provision of certified DNA labs, preparation of the DNA Initiative syllabus, synchronization of industrial curriculum, implementation of learning with the curriculum of DNA, implementation of street vendors/internship work, exam and certification, opening of ESP (Evercos Service Partner), evaluation, and cooperation improvement. Based on the results of FGD, the implementation of the DNA Initiative learning model for vocational students is very effective and appropriate.

\section{REFERENCES}

Acs, Z. J., Szerb, L., \& Lloyd, A. (2017). Global Interpreneurship Index 2018. Washington DC: The Global Entrepreneurship and Development Institute.

BPS. (2016). Angka Pengangguran Indonesia. Jakarta: Indonesian Central Bureau of Statistic. Depdiknas. (2016). Mengembangkan Kerja Sama yang Efektif antara Lembaga Diklat Kejuruan dan Industri. Jakarta: Deutsche Gesellschaft Fur.

Finch, C. R., \& Crunkilton, J. R. (1999). Curriculum development in vocational and technical education: Planning, content, and implementation. Needham Heights: Allyn \& Bacon.

Isa, A. (2010). Keefektifan pembelajaran berbantuan multimedia menggunakan metode inkuiri terbimbing untuk meningkatkan minat dan pemahaman siswa. Jurnal Pendidikan Fisika Indonesia, 6(1).

Joyce, B., Calhoun, E., \& Hopkins, D. (2008). Models of learning, tools for teaching. Singapore: McGraw-Hill Education.

Karnes, M. R., Baldwin, T. R., Barnett, E. J., Bensen, M. J., Bjorkquist, D., Brusic, S. A., ... \& Dyrenfurth, M. J. (1999). Technology education in prospect: Perceptions, change, and the survival of the profession. The Journal of Technology Studies, 11-35.

BPPB. (2016). Kamus Besar Bahasa Indonesia. Jakarta: Badan Pengembangan dan Pembinaan Bahasa, Indonesian Ministry of Education and Culture.

Moleong, L. J. (2007). Metodologi Penelitian Kualitatif. Bandung: Remaja Rosdakarya.

MONE. (2003). Law number 20/2003 about the National Education System. Jakarta: Indonesian Ministry of National Education.

Stevenson, J., \& Stevenson, J. C. (Eds.). (2003). Developing vocational expertise: Principles and issues in vocational education. Crows Nest, NSW: Allen \& Unwin.

Stevenson, R. B. (2007). Schooling and environmental/sustainability education: From discourses of policy and practice to discourses of professional learning. Environmental education research, 13(2), 265-285.

Strauss, A., \& Corbin, J. (1990). Basics of qualitative research. Thousand Oaks: Sage Publications.

Purnadi, Kuat,T., \& Santosa, B. (2018). Effectiveness of the network device application initiative learning model towards the students' information and communication technology skills. Journal of Vocational Education Studies, 1(1), 1-6. DOI: https://doi.org/10.12928/joves.v1i1.586. 
Surachim, A. (2016). Efektivitas Pembelajaran Pola Pendidikan Sistem Ganda. Bandung: Alfabeta. 
Purnadi, Kuat,T., \& Santosa, B. (2018). Effectiveness of the network device application initiative learning model towards the students' information and communication technology skills. Journal of Vocational Education Studies, 1(1), 1-6. DOI: https://doi.org/10.12928/joves.v1i1.586. 